$10-2001$

\title{
Nāgārjuna's Theory of Causality: Implications Sacred and Profane
}

Jay L. Garfield

Smith College, jgarfield@smith.edu

Follow this and additional works at: https://scholarworks.smith.edu/phi_facpubs

Part of the Philosophy Commons

\section{Recommended Citation}

Garfield, Jay L., "Nāgārjuna’s Theory of Causality: Implications Sacred and Profane" (2001). Philosophy: Faculty Publications, Smith College, Northampton, MA.

https://scholarworks.smith.edu/phi_facpubs/23 


\section{UNIVERSITY of \\ HAWAI'I \\ PRESS}

Nāgārjuna's Theory of Causality: Implications Sacred and Profane Author(s): Jay L. Garfield

Source: Philosophy East and West, Vol. 51, No. 4, Nondualism, Liberation, and Language: The Infinity Foundation Lectures at Hawai'i, 1997-2000 (Oct., 2001), pp. 507-524

Published by: University of Hawai'i Press

Stable URL: https://www.jstor.org/stable/1400165

Accessed: 03-08-2018 15:54 UTC

JSTOR is a not-for-profit service that helps scholars, researchers, and students discover, use, and build upon a wide range of content in a trusted digital archive. We use information technology and tools to increase productivity and facilitate new forms of scholarship. For more information about JSTOR, please contact support@jstor.org.

Your use of the JSTOR archive indicates your acceptance of the Terms \& Conditions of Use, available at https://about.jstor.org/terms

University of Hawai'i Press is collaborating with JSTOR to digitize, preserve and extend access to Philosophy East and West 


\title{
NĀGĀRJUNA'S THEORY OF CAUSALITY: IMPLICATIONS SACRED AND PROFANE
}

\section{Jay L. Garfield}

Department of Philosophy, Smith College, and School of Philosophy, University of Tasmania

\section{Introduction}

Nāgārjuna properly emphasizes that one understands the fundamental nature of reality (or lack thereof, depending on one's perspective) if, and only if, one understands the nature of dependent origination:

\author{
Whoever sees dependent arising \\ Also sees suffering \\ And its arising \\ And its cessation as well as the path. (XXIV:40)
}

And he devotes two important chapters of the Mülamadhyamakakārikā to the analysis of causality per se and of dependent arising more generally. The analysis developed in these chapters permeates the rest of the treatise. I have largely said my piece about how these chapters are to be read and about their role in Nāgārjuna's larger philosophical enterprise (Garfield 1990, 1994, 1995). I will review that account only briefly here as a preliminary to some applications.

I think not only that Nāgãrjuna is right about the fundamental importance of causality, and of dependence more generally, to our understanding of reality and of human life but also that his own account of these matters is generally correct. Given these two premises, it follows that our conduct of natural science as well as the pursuit of our moral life should be informed by Nāgārjuna's account of these matters. Here, I will develop some of these implications. I caution, however, that my development, at least in the case of ethics, is heterodox-although, as I will argue, absolutely orthodox Madhyamaka-within at least one major living tradition in which Madhyamaka is preserved and practiced: the dGe lugs pa school of Tibetan Buddhism. As a consequence, we will have reason to question both certain substantive claims made within that tradition about the necessary conditions of the cultivation of bodhicitta and the doxographic strategy of the tradition.

My claims about the philosophy of science may be less controversial, but will nonetheless offend some. And that (on both counts) is as it should be. For the philosophy of science has been steadily maturing into a more Buddhist framework over the past few decades (even if most Western philosophers of science would not recognize that characterization). But there are residues of pre-Buddhist modernism in practice, and even those who opt for a more enlightened approach to these matters do not always see the big picture. 
I will first sketch Nāgārjuna's view. The account will be straightforward, and I will not defend my reading any further here. I will then turn to the implications of this view for the philosophy of science, arguing that Nāgārjuna's account of interdependence shows how we can clearly understand the nature of scientific explanation, the relationship between distinct levels of theoretical analysis in the sciences (with particular attention to cognitive science), and how we can sidestep difficulties in understanding the relations between apparently competing ontologies induced by levels of description or explanation supervening on one another.

Finally, I will examine rGyal tshab's exposition of Dharmakirti's account, in the pramānasiddhi chapter of the Pramānavarttika, of the necessity of a belief in rebirth for the cultivation of bodhicitta. This account is accepted in the dGe lugs tradition both as an accurate representation of Dharmakīrti's views and as authoritative regarding bodhicitta and the mahākarunā, which is its necessary condition. But, I will argue, Dharmakirti, rGyal tshab, and their followers are, by virtue of accepting this argument, neglecting Nāgārjuna's account of dependent arising and in consequence are implicated in what might be seen from a proper Prāsangika-Madhyamaka point of view as the very subtlest form of self-grasping. We can use Nāgārjuna's account to extirpate this final self-grasping, thus freeing the morally central notion of bodhicitta from unnecessary and perhaps implausible metaphysical and cosmological baggage. This also suggests some caution regarding a doxography that takes as axiomatic the consistency of Dharmakīrti's pramānavāda and Nāgārjuna's Madhyamaka. We will conclude with a few observations on common lessons emerging from these applications of Nāgārjuna's insights in two such radically different domains.

\section{The Emptiness of Causality}

Nāgārjuna is often erroneously understood as a nihilist with respect to causality and dependent arising. On this misreading he is taken to argue that in fact there are no relationships of mutual dependence among phenomena, and even that no phenomena in fact exist. Nothing could be further from the truth. Nāgārjuna assiduously defends the co-relativity of emptiness and dependent arising, and insists that to say that all phenomena are empty just is to say that they are dependently arisen:

\footnotetext{
Whatever is dependently co-arisen

That is explained to be emptiness,

That, being a dependent designation, Is itself the middle way.

Something that is not dependently arisen,

Such a thing does not exist.

Therefore a nonempty thing

Does not exist. (XXIV : 18-19)
}

Since nobody-particularly anyone who would offer a nihilistic reading of Nāgārjuna with respect to the conventional world and pratitya-samutpāda-would seriously claim that Nāgārjuna denies the emptiness of all phenomena, nobody who 
reads the Mūlamadhyamakakārikā through to the end could seriously defend the nihilistic reading.

Since one of the principal phenomena that Nāgārjuna analyzes as empty is causation, it is not surprising that some read the first chapter of the Mülamadhyamakakārikā as an attack on the reality of causation. After all, in the very first verse he asserts:

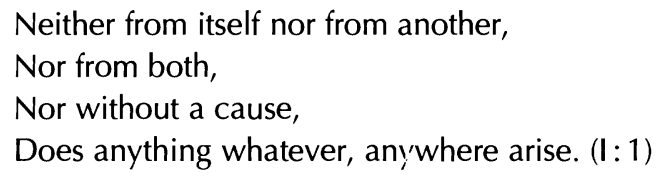

But again, given a correct middle-path reading of Nāgārjuna's program, we can see immediately that such a reading must be erroneous. Nāgārjuna's strategy throughout the Mūlamadhyamakakārikā is to argue that the phenomena we normally take to be inherently existent, to have convention-independent natures, and to exist as they do precisely because of their natures are in fact empty of inherent existence, exist only conventionally, and exist precisely because of their emptiness and interdependence. To quote a favorite Tibetan Prāsanigika-Madhyamaka saw: we do not say that because things are empty that they do not exist; we say that because things exist they are empty. The converse, of course, is equally assertible.

Now, as I have argued before, in the case of causation, in chapter 1 of the Mūlamadhyamakakārikā, Nāgārjuna proceeds by distinguishing hetu (rgyu) from pratyaya (kyen). He uses the former term to denote the cause of the metaphysicians - an event capable of bringing about another by virtue of a power that is part of its nature. The latter denotes an event or phenomenon whose occurrence or existence is correlated with that of another-a condition:

These give rise to those,

So these are called conditions. $(1: 5 a, b)$

"When this arises, so does that. When this ceases, so does that." Of course Nāgārjuna identifies four kinds of conditions, in rough harmony with standard Buddhist taxonomies of causality (for more detail see Garfield 1995). He argues that the midpoint between reification of causation - the adoption of a realistic view with respect to causal powers - and nihilism - the view of a random and inexplicable universe of independent events-is the acceptance of the reality of conditions, and a regularist account of explanation. On such a view, what counts as explanans and as explanandum depends on explanatory interests and upon conventions for individuation and classification. Hume is often read (properly in my view) in roughly this way. Such a view is, hence, far from a nihilism. This is instead a moderate, sensible approach to explanation and to understanding.

Nāgārjuna's reasons for rejecting causal powers anticipate the arguments of Hume and of Wittgenstein: causal powers are never observed; causal powers, if sufficient for explanation, can never inhere in isolated events or things, which always require cooperating conditions; causal powers cannot be explanatory on 
pain of regress (what would explain the arising of the powers, or their giving rise to effects?); and positing causal powers imposes implausible uniformity on the explanatory landscape. These arguments are by now familiar, if still controversial, and this analysis of the first chapter of the Mūlamadhyamakakārikā is by now familiar, if still controversial. I have defended these positions elsewhere (Garfield 1990, 1994, 1995), and merely recall them here in order to use them as a platform for extension.

Nāgārjuna's conventionalist regularism, when joined with his eclectic view about the dimensions of explanation represented in the account of the four kinds of conditions (efficient, supporting, immediately preceding, and dominant), gives rise to a reasonably straightforward analysis of explanatory and predictive language: we explain a phenomenon when we identify it as of a kind; when we connect occurrences of things of that kind with the occurrence of other related phenomena; when we connect the macroscopic and easily observable with the microscopic and harder-to-observe; and when we place it within a network of events, purposes, and connections that form patterns enabling rational action, prediction, and cognitive access to the world.

The serious causal realist (really a reificationist in Nāgārjuna's sense) can be expected to press against Nāgārjuna the obvious question for any such regularist: what explains these regularities, if not genuine causal powers inhering in genuine causes? ${ }^{1}$ After all, anyone who is even as realistic as Nāgārjuna, and as committed to the enterprise of explanation as Nāgārjuna, must be committed to explaining why the explanans appealed to in any explanation in fact explains and, in the end, why the world is regular at all. Appeal to causes and their powers would do this; anything less leaves the entire structure mysterious. ${ }^{2}$

Nāgārjuna's reply in chapter VII of the Mūlamadhyamakakārikā is straightforward: each regularity, each pattern, each connection posited in any explanation must indeed be explicable. That is the content of pratitya-samutpāda. But each is explained by still further regularities, patterns, connections. Deeper understanding consists of the increasingly richer embedding of interdependence into larger, more articulated patterns of interdependence. And there simply is no explanation of why the entire universe is interdependent. There is no such well-defined totality to explain:

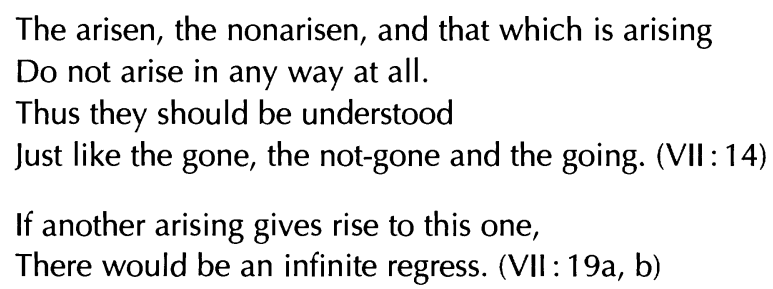

That is the problem of the limits leading to the unanswerable questions. Explanatory questions are always local. Attempting transcendental explanations of the possibility of explanation is not only fruitless, it is meaningless: what could explain why explanation itself is possible? Certainly not powers. What could explain them, or, more deeply, their explanatory potential, if not the patterns into which they are embedded? 
We have, then, in the Mūlamadhyamakakārikā, articulated principally in chapters I and VII but supported in a myriad of ways throughout the text, an account of explanation and causation that, like Hume's, grounds ontology in the conventions that underlie our explanatory interests and the sortals we choose under which to collect entities, and not in a self-evident or self-presenting partition of nature into things, properties, and relations. This is, of course, an ancient view, developed and defended long before the rise of modern science. For all of that, it provides a natural and compelling guide to the landscape of the world as captured by the scientific image. Let us now turn to the important implications of this way of seeing things for contemporary science.

\section{A Madhyamaka View of Scientific Explanation and Ontology}

If we survey the world as it is understood in contemporary science, and contemporary science as it develops in order to understand the world, we are immediately struck by the fact that from whichever way we approach the enterprise-whether from the standpoint of theory or from that of the object(s) of theory-multiple levels of explanation or of ontology present themselves. Economics, sociology, anthropology, psychology, neuroscience, ecology, cell biology, physiology, chemistry, fluid dynamics, macrophysics, and quantum theory each proceed and indeed progress. Each develops a proprietary vocabulary, methodology, explanatory strategy, and ontology. We have become accustomed-or at least we had better become accustomed-not only to the peaceful coexistence of departments of each of these disciplines in our science faculties, but also to the peaceful coexistence of the phenomena they posit at their various levels of description and explanation: not only do departments of economics and of theoretical physics both exist, but exchange rates and neutrinos both exist as well.

This multiplicity of kinds of theories and of things sets much of the agenda for contemporary philosophy of science and metaphysics. For as soon as a categorial multiplicity is countenanced, there is an imperative either to reduce or to systematize it. Is the multiplicity real, or only apparent? Is one level fundamental? Are the relations between the levels uniform? Ordered? What determines a level? And so on.

Ontology and methodology become even more vexed when a single phenomenon appears to be explicable on multiple, prima facie orthogonal axes of explanation: is a movement of my arm to be explained by appeal to muscle contractions, neuromuscular synaptic events, and a neurophysiological story? Is it to be explained by reference to my beliefs and desires, by reference to the cultural practices of my fellows, or by reference to the need to greet a friend? If one level is to be privileged, which one, and why? But if multiple levels, how can such mutually independent, individually complete accounts of the necessary and sufficient conditions of the same object be equally acceptable?

Now, as anyone who has even a passing familiarity with contemporary metaphysics and philosophy of science knows, debates about these issues quickly become baroque. But we can cut through the Gordian knot if we slice at the right angle, and here is where Nāgārjuna's analysis helps us; for all of these questions and 
puzzles can be sorted into two closely related, but nonetheless distinct classes: the ontological and the methodological. The first class asks to which entities and properties we ought to commit ourselves. The second asks how we should understand the relationship between theories and explanations pitched at distinct levels of analysis.

A Madhyamaka answer to questions of the first kind is a straightforward catholic realism: accept the deficits of economics, the kinship relations of anthropology, the classes of sociology, the beliefs of psychology, the molecules of chemistry, the niches of ecology, and the quarks of physics. Nāgārjuna's version of the Quinean dictum is that to be is to be the value of a bound variable is simply "to exist is to exist conventionally, dependently." The relevant conventions here are those of scientific theory, and the relevant dependencies are given by the laws discovered by science. From this perspective there is motivation to disparage neither the "high"-level phenomena of the social or biological sciences in favor of an ontological primacy accorded to the "low"-level phenomena of the physical sciences (see Churchland 1978) nor the "unobservables" of the latter in favor of the manifest entities of the latter (van Fraassen 1980).

For our purposes, it is important to see that this ontological generosity emerges precisely from Nāgārjuna's analysis of causality and explanation. It is best to come at this through a via negativa or, as I should say in the present context, a prāsanga: the urge to privilege one level over another always emerges in science and in the philosophy of science from a view about where genuine causation is to be found. We might, following Churchland (1978), argue that because genuine causation is physical causation, by virtue of real causal power inhering in subatomic particles, only the physical is really real, and all phenomena described at higher levels are real only to the extent that they are reducible to the physical. Or, following van Fraassen (1980), we might reject the unobservable because real causal laws connect observables. ${ }^{3}$ In either case, we justify an ontological distinction based on a claim about where causal powers are to be located, and this because the only genuine explanations, explananda, and explanans are those respectively adverting to, deriving from, and possessing causal powers. But once we free ourselves from the thrall of this image of explanation and its ground, the motivation for these distinctions crumbles. Then we can pay attention to pratitya-samutpāda-to interdependence and its multiple, multidimensional, inter-level, and intra-level character-and let a thousand entities bloom, requiring of each that it genuinely toil and spin, accomplishing some real explanatory work. ${ }^{4}$

Maintaining our focus on this notion of "explanatory work" as the bulwark against ontological profligacy, we can return to dispose quickly of the second class of puzzles noted above: those regarding not levels of ontology but levels of theory. Where competing explanations are offered, or where competing sciences vie as candidates to explain particular phenomena, which of these-other things being equal-should claim our theoretical allegiance? Of course, if we seriously believed in the cement of the universe, the answer to this question would be easy: the theory or the science founded in that very cement. The rest would then properly be regarded as pretenders or "what to do until the real science comes along." But if all 
that explanation tracks is regularity and, as Nāgārjuna would have it, the increasingly rich embedding of regularity, the answer to the query is equally simple: if other things are really equal, then take 'em all. Again, this does not mean that we should accept just any conjecture or explanation, together with the ontology it implicates. All of the standard desiderata of good theories apply-economy, elegance, predictive power, confirmation, coherence with other theories, and so forth. The point is rather that these desiderata are all that matter. And that is because beyond pratityasamutpāda there are no occult causal powers lurking as the unique and genuine targets of our theoretical activity.

These issues are particularly sharp in cognitive science, where naturalistic, intentional explanations vie with eliminative and cognitive neuroscience, nonlinear dynamic theory, computational models, and so forth. Now, many of these debates are straightforwardly empirical debates about how best to understand a particular cognitive phenomenon, and about whether a particular theory is successful on its own terms. Neither Nāgãrjuna nor any other philosopher of science has anything to contribute to these debates. This is as it should be. These are all issues to be settled in the laboratory.

But some (e.g., see Churchland 1978 and Fodor 1987, among many others) would resolve these debates on a priori grounds, arguing, for example, (1) because naturalistically individuated states cannot have causal powers they cannot explain anything and are not real psychological states, and so psychology must be individualistic, or (2) because causation in the mind is ultimately a neural phenomenon, and so no phenomena other than those described in the language of neuroscience are psychologically real, that only neuropsychology is possible. Others (see Burge 1979) argue that since all psychological phenomena are intentional, and since it is under intentional descriptions that they are causally active, psychological phenomena can only be individuated and explained naturalistically. To all of these, Nāgārjuna's analysis of pratitya-samutpãda should lead us to answer, using a Sanskrit technical term from pramāna theory, "fiddlesticks."

As many philosophers of cognitive science have argued (see Garfield 1988, Hardcastle 1996, and von Eckardt 1995), many empirical domains comprise phenomena whose explanation must proceed simultaneously at distinct levels of description, using theories and vocabularies that are, while mutually consistent, methodologically orthogonal to one another. Such theories may be mutually irreducible, and their vocabularies often comprise terms indefinable in terms of theories at distinct levels. The only relations between such theories might be those of global supervenience. None of this, however, requires anything but robust realism regarding each level, and regarding the entities posited by each theory. Only a dogmatic ideology regarding the unity of science could lead one to any different conclusion. ${ }^{5}$ Nāgārjuna would smile.

\section{Bodhicitta and Rebirth: A Heterodox Madhyamaka View}

So much for the profane. Now we will turn our gaze back to Buddhist metaphysics and epistemology proper. We will find that even in that domain the full import of Nāgārjuna's views has not always been appreciated. I will argue that a claim about 
the preconditions for the cultivation of bodhicitta-the most ethically and soteriologically significant motivational state in Mahāyāna Buddhist ethics - that is taken as well established in the dGe lugs pa tradition of Tibetan Buddhism is in fact inconsistent with Nāgārjuna's account of dependent arising, involves a subtle form of self-grasping, and so, by the lights of the tradition itself, should be rejected. That claim is this: the cultivation of bodhicitta - the altruistic aspiration for buddhahood for the sake of the liberation of all sentient beings from samsāra-requires the belief in rebirth.

There is a hermeneutic fallacy in Western philosophy that I call "Farabi's fallacy," after its most spectacular exponent. It goes roughly like this: $\mathrm{X}$ was a really smart philosopher. $\mathrm{Y}$ was a really smart philosopher. Two such smart guys were undoubtedly both right. So, even though it might look like their views aren't consistent, they must be, and the task of a successful philosophical hermeneutics is to weld them together. Farabi tried it for Plato and Aristotle. Aquinas, inspired by that noble failure, tried it for God and Aristotle. In the Tibetan tradition the gold medal for Farabi's fallacy undoubtedly goes to the founder of the dGe lugs school, rje Tsong khapa, who at some point said, "Nāgārjuna-what a smart guy! Dharmakīrti-what a smart guy! So, despite the fact that sunyavāda and pramānavāda might look like two vādas diverging in a yellow wood, they must be consistent." Tsong khapa (unlike Frost) devoted much of the rest of his philosophical life to the task of demonstrating and working out the consequences of their consistency, trying to take both roads simultaneously. Now, I have enormous admiration for Tsong khapa as a philosopher, and he is arguably the titan of the Tibetan philosophical tradition. But in this respect I find his influence less than salutary.

The locus classicus for the dGe lugs argument for the conclusion that belief in rebirth is a necessary condition of the cultivation of bodhicitta is Tsong khapa's student rGyal tshab's commentary on the pramānasiddhi chapter of Dharmakīti's Pramānavarttika. On reading this chapter one might well wonder why immediately after a discussion of bodhicitta Dharmakirti sets out to prove the existence of past and future lives. rGyal tshab's commentary on this passage explains this juxtaposition by setting up a materialist argument against the establishment of rebirth and argues that such a view is inconsistent with the cultivation of bodhicitta. The argument is interesting from our point of view not only because it is spectacularly bad, but also because its error consists precisely of its failure to appreciate the import of Nāgārjuna's account of causality and its implications for the selflessness of the person. As a consequence we shall see Dharmakirti and rGyal tshab caught up in what I think of as the subtlest form of selfgrasping a Buddhist could imagine, but a self-grasping nonetheless.

[252.2] When the one endowed with great compassion became a sage, that required precursors: first, having developed a compassionate desire to free beings from all their sufferings, it was necessary for him to familiarize himself with a method for thoroughly pacifying the suffering in order to become a teacher.

With respect to great compassion: it is arisen neither causelessly nor from irrelevant causes. It arises from previous familiarity with things of the same kind. Great compassion itself is what establishes one on the beginning of the practice of the Mahāyāna path. 
[252.11] It isn't accomplished through familiarity with various kinds of compassion, and it doesn't come from prior births. That is because since the conceptual mind depends on the body, if the body is destroyed, the mind will be destroyed as well. For example, just as light comes from a lamp, it [mind] is the effect of a body, just as the ability to get drunk from beer is a characteristic of the body; just as a picture depends on the wall; through its very nature, it [mind] depends on it [body].

[252.18] With respect to the conceptual mind: this body is neither its cause nor its supporting condition, and therefore the mind does not depend on it. This is because since that [the body] is the basis [of the mind and] can be refuted through reasoning, it will be rejected. Moreover, from giving reasons for the nonexistence of past and future lives [253] it would follow that familiarity with the arising of the various compassions would not be appropriate. Since this is not the case, through refutational reasoning this will be rejected. Therefore, since through good reasoning past and future lives are established, it follows from this-and on the fruit to be discussed below-that it is clearly established that one can obtain a favorable rebirth in a future life. Having proven this, and thus having established the Four Noble Truths, in that way one proves the excellent consequences of abandonment, of causes and effects, upon which beings of the three capacities should meditate in common. Thus [the practitioner,] adorned with constantly increasing boundless compassion, through having achieved a complete realization of the Four Noble Truths establishes the way to achieving omniscience.

[253.17] With past and future lives having been well established And with their absence having been refuted

Self is refuted and on that basis evil is abandoned.

The argument in outline runs as follows. Great compassion (mahākarunā-the highest level of compassion achieved by the bodhisattva, characterized as compassion in regarding sentient beings as empty of inherent existence) is essential to the enlightenment of a bodhisattva. It is also hard to achieve, requiring many rebirths in which one accumulates its causes, and in which one becomes familiar with compassion and with the view that underlies it. Now, bodhicitta is the altruistic aspiration to gain enlightenment for the sake of other sentient beings, and a fortiori the aspiration to achieve this level of compassion. But that is only possible given many rebirths. So one cannot coherently develop this aspiration if one does not believe in the requisite rebirths. So even to develop bodhicitta one must believe in rebirth. This is the argument on which I want to focus, and note that it is independent of the preceding argument specifically for the existence of rebirth.

Think about the bodhisattva resolution in any of its standard formulations: I will attain enlightenment for the sake of all sentient beings; or, in Śantideva's more poetic words, from Bodhicaryāvatāra 10.55:

For as long as space remains;

For as long as transmigrators remain;

So long will I myself remain, and thereby

I will relieve all transmigrators' suffering. (Bodhicaryāvatāra 10:55)

Jay L. Garfield 
But who, or what, is this " $\mathrm{I}$ "? And what is its role in the expression of bodhicitta, particularly in the context of a Buddhist doctrine of anātman? Now, of course it is not intended to be a substantial self of the kind that all Mādhyamikas reject. And we don't want simply to dismiss these formulas as confused or nonsensical, as a nihilist about the self might. But just noting that it is Madhyamaka's familiar conventionally real but ultimately nonexistent "mere I" will also be too facile. For, the argument we have just surveyed for the connection between belief in rebirth and the cultivation of bodhicitta hinges directly on the need to posit this " $\mathrm{I}$ " in past, present, and future lives as the basis of the causal continuum linking the extraordinarily many causes of buddhahood and the effect. It is, hence, doing real metaphysical work, well above and beyond what any "mere," nominally posited " $\mathrm{l}$ " could ever do: it is functioning as the basis for a real causal relation. If it were not needed for this, there would be no bar to a far simpler account of the aspiration for the liberation of all sentient beings (the one I will shortly defend) according to which the relevant aspiration is just that someone will attain Buddhahood, and that lots of people will have to do lots of stuff to make that possible. These causes will cooperate over time to enable the requisite enlightenment, and the practitioner resolves to contribute to that accumulation of causes. The fact that this option is not even considered by Dharmakirti or rGyal tshab suggests that another view of the relevant causal process is at work. Let us explore this in more detail.

Following Dharmakirti, rGyal tshab takes himself to be responding directly to a materialist opponent who denies the reality of rebirth, arguing:

It isn't accomplished through familiarity with various kinds of compassion, and it doesn't come from prior births. That is because since the conceptual mind depends on the body, if the body is destroyed, the mind will be destroyed as well. For example, just as light comes from a lamp, it [mind] is the effect of a body; just as the ability to get drunk from beer is a characteristic of the body; just as a picture depends on the wall; through its very nature, it [mind] depends on it [body].

It is argued by rGyal tshab that there must be rebirth precisely because "[compassion] arises from previous familiarity with things of the same kind" and that "from giving reasons for the nonexistence of past and future lives it would follow that familiarity with the arising of the various compassions would not be appropriate." On the other hand, if, and only if, there is rebirth, he asserts that "adorned with constantly increasing boundless compassion, through having achieved a complete realization of the Four Noble Truths [the practitioner] establishes the way to achieving omniscience." That is, it is only personal rebirth-here defined explicitly in terms of a single mental continuum independent of the body - that for rGyal tshab (and Dharmakîrti) and the subsequent dGe lugs pa tradition makes buddhahood possible, and so only a belief in this possibility could ground bodhicitta-the resolution to achieve buddhahood for the sake of sentient beings.

Note that this implicates two specific theses: one regarding causality and one regarding the content of compassion. Both, I will argue, are misguided from a Madhyamaka perspective. The first, especially, is inconsistent with Nāgārjuna's own 
account of causality. The second is implicated by it and is inconsistent with the doctrine of anātman.

A central claim in rGyal tshab's argument is that without rebirth there cannot be any causal connection between the accumulating causes of bodhicitta and mahākarunā (accumulation of merit and wisdom and familiarization with compassion and its objects) and the crucial effect. That is why rGyal tshab can say that "from giving reasons for the nonexistence of past and future lives it would follow that familiarity with the arising of the various compassions would not be appropriate." And that is why he can say that the fact that there are past and future lives enables "the excellent consequences of abandonment, of causes and effects, [and] ... constantly increasing boundless compassion, through having achieved a complete realization of the Four Noble Truths establish[ing] the way to achieving omniscience."

But why should rebirth be necessary to mediate this causal link? We (where "we" includes both Dharmakìrti and rGyal tshab) are quite familiar with causal chains in which important causes are present in one group of entities and the effect in others (a tinderbox and flint give rise to a fire that burns in a candle and is used to light a lamp; a teacher's words together with the text in a book give rise to understanding in the mind of a student; etc.). And this last provides a plausible alternative model for the accumulation of causes of mahākarunā, bodhicitta, and omniscience: the acts, insights, writings, and discoveries of one individual make possible deeper insights, more profound realizations, and more informative writings on the part of another. Knowledge and compassion deepen over the generations, and, after a time, some individual attains buddhahood as a consequence of the accumulation of causes by others. Call this the transpersonal model of attainment, as opposed to the intrapersonal model embraced by the dGe lugs pa tradition, following Dharmakīti and rGyal tshab.

The questions we must ask, then, are these: (1) Why does rGyal tshab embrace the intrapersonal rather than the transpersonal model? (2) Is his doing so consistent with Nāgārjuna's account of causation? I think that the answer to the first is obvious, and this is confirmed by the oral tradition: ${ }^{6}$ only an interpersonal continuum could mediate the connections between the relevant causes and effects. Remove this premise and the argument loses all plausibility. After all, given that it is reasonable to believe that buddhahood is difficult to achieve, one could argue convincingly that bodhicitta requires a belief in the past and the future, but not in one's own past and future lives, unless one thought that the relevant causal chain could only be intrapersonal. But why would rGyal tshab believe that? Well, the only reason I can come up with is that he thinks that causation requires a substantial basis-something in which the causal powers inhere. That basis, for rGyal tshab, would be the mental continuum or subtle consciousness that continues across rebirths.

And that implausible view leads us to the next question: is that consistent with Nāgārjuna's account of causation, which rGyal tshab and the dGe lugs tradition also endorse? No, of course not. For Nāgārjuna, insisting on the emptiness of causation, insists precisely on the absence of the need for any causal powers or for any substantial basis for causal chains. Causation is re-described in his Madhyamaka anal- 
ysis as a matter of explanatorily useful regularities, and the notion of explanatory utility is further unpacked in terms of the embedding of regularities in further regularities. None of this requires the genidentity of the objects participating in cause and effect. Nor should it, as countless counterexamples show. Here the Cārvaka opponent seems to get things just right: "It isn't accomplished through familiarity with various kinds of compassion, and it doesn't come from prior births. That is because since the conceptual mind depends on the body, if the body is destroyed, the mind will be destroyed as well." Or at least it could be like that.

Moreover, returning to the second thesis central to rGyal tshab's accountconcerning the content of compassion-it would be more in harmony with the Mahāyāna understanding of anātman (also defended forcefully by Nāgārjuna in the Mūlamadhyamakakārikā) to see it like that. This brings us back to the status of the "I" in verses like Santideva's and the real content of bodhicitta and the mahākarunā that it comprises. The aim and the motivation of bodhicitta is the alleviation of the suffering of all sentient beings. That is beyond question. It also comprises the view that only a buddha could accomplish this task, given its stupendous difficulty. Moreover, bodhicitta is more than a mere wish that a buddha arise and that thereby sentient beings be released from suffering; it is an altruistic aspiration to bring this about. And the notion of "bringing about" is, of course, ineliminably causal. One can see, then, how if one thought about causality in terms of substantial supporting bases of causal chains one would then be led to believe that the only way one could bring about the arising of a buddha for the sake of other sentient beings is to set about becoming one oneself, and the only way one could rationally adopt that objective would be to believe in past and future lives - and the rest follows.

But once we have shed the reified view of causality that Nāgārjuna so forcefully criticizes, this argument crumbles. And once we accept something like the transmission of knowledge as an analogy for a transpersonal causal chain linking epistemic and moral causes with their soteriological effects, we can see that the "I" as a future-tense subject in the bodhisattva resolution is gratuitous. I must develop an altruistic resolve to do something; that something - if we accept more Buddhist soteriological theory about the necessity of a buddha's capabilities for the task at hand - might be to bring about enlightenment (or at least to contribute to bringing it about); but that enlightenment need not be mine. And if it need not, there is no entailment at all between bodhicitta properly understood and rebirth.

Nor should there be. For now we can see that to confuse an altruistic impersonal aspiration for enlightenment for the sake of sentient beings with an aspiration for one's own enlightenment-to confuse a conviction that there is a future for the sake of which one should work with the view that it is one's own future-is a serious, though subtle form of ātmanvāda or even ātmangrāha. The reason is this: the "I" that is posited here is posited not merely as a conventionally designated continuum, but as a substratum for a causal process. My dGe lugs proponent at this point-accusing me of nihilism about the self-will protest that the "I" so posited is a mere "I" ("nga" tsam) as opposed to a substantial self. But simply to say that this is what is going on doesn't make it so. Here's the difference: a mere "I" doesn't do any metaphy- 
sical work-it serves as a conventionally posited imputation with no conventionindependent identity conditions, and no explanatory value. Candrakīrti $(1989,1994)$ as well as Nāgārjuna and later Tsong khapa $(1984,1988)$ make this point with great force. But the "I" posited here-the "I myself" (bdag ni) of Śantideva, the one that is reborn for rGyal tshab-has work to do. It explains causation, something that neither Nāgārjuna is in need of an explanation of nor is capable of being explained. To posit such a substantial substrate and then to stake the meaning of one's moral life on its continuation through time is to fall back from a view of emptiness into a barely disguised substantialism about the self. Only by opting for a more impersonal bodhicitta, a more impersonally bodhisattva resolution, can the Mahāyāna remain consistently Madhyamaka.

I have heard three further objections to this account from dGe lugs pa interlocutors. Let me rehearse and respond to each quickly before turning to my conclusion.

(1) In your view, it doesn't matter what I do in this life-whether I am Hitler or Mother Theresa, and this for two reasons: (a) If I am not going to exist in the future, I have no moral incentive to be good; after all, I will neither reap the benefits of morally good actions nor suffer the consequences of morally bad actions. (b) Either kind of life might lead to benefits in the future, so there is no intrinsic reason to prefer a good life to a bad one. The answer in each case is simple. Concerning the first objection, if your only motivation for leading a good life is your own benefit in the future, your motivation is not that of a bodhisattva in the first place. We are considering the necessary conditions of bodhicitta, after all, not of self-interest. Concerning the second, the reason for thinking that Mother Theresa's life will be more likely to lead to universal moral improvement and enlightenment than Hitler's is not intrinsic by anyone's reckoning: it is causal (and although fallible, plausible). We think that it is simply more likely that lives like hers generate the relevant moral benefits better than lives like his. If we thought otherwise, altruism might require strange things of us. ${ }^{7}$

Others object (2) that there are plenty of independent reasons to accept rebirth (Dharmakirti and rGyal tshab would agree). Maybe so. Maybe not. It doesn't matter, I say, for the present purposes. My question is this: do you need to believe in rebirth in order to generate bodhicitta? Just as it is true both that there are nine planets and that it is unnecessary to believe this in order to cultivate bodhicitta, it may be true that there is rebirth. But even if it is, I have argued that it is unnecessary to believe this in order to cultivate bodhicitta. It is only the entailment that is at issue between rGyal tshab and me at this point. ${ }^{8}$

Finally, some of my dGe lugs pa colleagues ask, (3) if there is no rebirth, how does anyone get to the point of buddhahood, given the stupendous difficulty, or, indeed, to the point of generating bodhicitta, given its still impressive difficulty? Here I give the same answer I would give regarding how Kant wrote his Critique or how Einstein discovered relativity: by taking advantage of the accomplishments of those who go before. (Note that this is also a very plausible and a very attractive way of understanding refuge in Buddhist practice.) And that has been the burden of the foregoing argument. 
John Powers (personal communication) argues that the real reason for requiring a belief in past and future lives is the fact that since the bodhisattva vow requires one to work to attain buddhahood for the sake of all sentient beings, and since many of these sentient beings, in my view, fail to exist now (they have died), and since others will exist only far into the future, the vow would be incoherent. You can't, he argues, save sentient beings who no longer exist from anything, and a Buddha who then dies can't save future beings. In fact, he argues, if you don't believe in future lives, the best way to rescue all sentient beings from suffering is to kill them all, right now. These would be unacceptable consequences, of course. But they do not follow. Powers' charges, however, do force a careful examination of the content of the vow and of the aspiration as I must understand them. Bodhicitta must, in my view, be directed only to actual sentient beings, present and future. One cannot hope to do anything for the dead. That does, to be sure, reduce the scope of this moral aspiration, but only realistically so. With regard to the future, things are less dreary. The buddha that one strives to bring into the world, I would hope, would help not only her contemporaries but also her successors, just as the discoveries of medicines and vaccines help those who follow (the epithet "the great doctor" is a common way of referring to Siddhartha Gautama, and has just this connotation). Finally, while killing all sentient beings might indeed relieve suffering, it does not thereby bring out happiness, and bodhicitta surely is the aspiration to bring about happiness as well. "May all sentient beings be happy" is, after all, among the most common Mahāyāna colophons. I conclude that Powers' objections fail.

If I am right about this, the doctrine of rebirth is of considerably less importance to Buddhism - especially to Mahāyāna Buddhism — than it is generally taken to be. ${ }^{9}$ I take this as confirmation of my view. That doctrine, after all, is an import from an ambient Hindu culture. Buddhism jettisons a great deal of the central ideology of that culture, including, prominently, the ideal of attman; there is no reason to think that this part should survive, especially if it can be shown both to be inessential to the central moral theses definitive of the Mahāyāna and to be inconsistent with its central insights - those of anātman and of the emptiness of causation. ${ }^{10}$

\section{Conclusions}

I have referred to these distinct sets of implications of Nāgārjuna's views on causation as those for the profane and those for the sacred. But I could easily have adopted a more traditional classification of consequences: those pertaining to the selflessness of phenomena and those pertaining to the selflessness of persons. In each case, Nāgārjuna draws our attention to the subtle and seductive reification that comes to us so naturally, and to the extent to which our thinking about causation is implicated in that reification.

It is almost impossible to resist the temptation to seek to go beyond the merely interdependent and to posit some hidden glue-some cement of the universe-that holds in place not only the external world but the self, and that ensures the regular transition from link to link. "Surely," we think, driven by our deepest cognitive 
instincts, "even if everything we encounter is merely interdependent, that interdependence itself must have some substantial basis." But that commitment, when seen from the opposite side of the Madhyamaka dialectic, becomes the more insidious "surely, even if everything we encounter is empty, that emptiness must be truly existent." And once we commit that fallacy, we are set on the royal road to nihilism about the world in which we lead our lives, and to untenable realism about the transcendent. It then becomes impossible to make any sense at all of empirical reality or of its emptiness. So, tempting as the glue view is, it merely traps us in an inescapable web of metaphysical illusion.

Nāgārjuna's analysis is powerful not only because it dissolves the hidden glue we instinctively posit to give coherence to our world, but also because it demonstrates the pernicious consequences of positing that glue. While a theory about causation-even a prereflective theory-might seem to be but a recherché corner of metaphysics and the philosophy of science, it in fact infects and determines our view of everything else-from the philosophy of science to the philosophy of mind to cosmology to ethics. Getting clear about causality is indeed a prerequisite to getting clear about everything else; it is true that a world without inner and outer glue disintegrates. Nothing holds the self together; nothing holds causes to their effects. Raw interdependence is all we encounter, and there is no hope of an explanation to end all explanations. That is the manifestation in the philosophy of science and in the existential understanding of the nature of self of the abyss of emptiness into which Dōgen much later commands us to leap. But that leap is a leap into emptiness, and not into nihilism: just as Dōgen reassures us that in facing interdependence in this way the self and all things are affirmed, we have seen that in facing the emptiness of interdependence while the inefficacious occult cement of the universe vanishes, the empirical world and the possibility of meaningful life therein are affirmed. The mere interdependence provides all the coherence one could coherently desire.

Notes

Thanks to Arindam Chakrabarti for provoking me, to the Ven. Geshe Ngawang Samten for debating this issue, to Guy Newland and Mark Siderits for valuable contributions to the ensuing discussion from which this article has emerged, and to Mark for a valuable set of comments on an earlier draft. Thanks also to Georges Dreyfus for sending crucial texts, and to the Ven. Sonam Thackchöe for checking and correcting translations and for further discussion of these issues. I also thank Cynthia Townley and Tricia Perry for editorial assistance.

1 - I will not use the pejorative term "antirealist," for, in the context of Madhyamaka, that begs important questions both about the appropriate sense of "reality" and about what kinds of phenomena we might identify about which to be realists. Moreover, for a Prāsanigika-Mādhyamika like Nāgārjuna, there is an additional problem: how do we identify the common object necessary to generate a realist/antirealist debate? 
2 - Note that while this objection might appear to be a version of Smart's (1963) "cosmic coincidence" argument for scientific realism, it is not. For Nāgārjuna would agree with Smart that one must be (conventionally) realistic about anything one posits in an explanation. His claim is simply that in fact we never really posit causal powers in explanations (compare Tsong khapa 1984 and 1998 on the question of whether for a Prāsanigika —unlike a Svātantrika-we posit inherent existence even conventionally). The cosmic coincidence argument really does have its home in realism/antirealism debates, and this is not one of those. The question here is whether or not the concept of causal powers actually has any content. The reificationist claims that it does, Nāgārjuna that it does not.

3 - The contemporary philosophers most explicit about this justification for ontological discrimination in science are Jerry Fodor (1984) and Paul Churchland (1978).

4 - See also Kitcher 1993 for another contemporary argument for the claim that causal claims are grounded in explanations rather than vice versa. I thank Mark Siderits for calling this parallel to my attention.

5 - Mark Siderits (personal communication) charges me with adopting my own dogmatic ideology of the disunity of science, by virtue of underestimating or ignoring future theoretical unifications of the domains of these diverse sciences. This is not the place to fight this larger battle in the philosophy of science. I have said my piece elsewhere (Garfield 1988, unpublished). Briefly, though, while I endorse a broadly physicalistic view of the supervenience of the domains and theories of higher-level sciences on those of more fundamental sciences (e.g., psychology vs. physics), such supervenience does not entail for supervening sciences and domains either reduction to or absorption by the more fundamental sciences or domains, and the frequently relational, normative, or gerrymandered character of the ontologies and methodologies of higher-level sciences often blocks such reduction or subsumption. Multiple styles and axes of explanations are often necessary in order to capture the irregular, multilevel character of reality (see also Hardcastle 1996). Of course, this point depends to a certain degree on what one counts as reduction. If reduction is to be distinguished, as I (1988) and others (see Hardcastle 1996 and Churchland 1978, to cite but two examples) have argued they must be, reduction cannot simply be defined as global supervenience. Whether it is understood as a Nagel-style reduction by biconditional bridge laws or interlevel definitions, a systematic reduction as in Haugeland 1981 or Cummins 1983 , or the preservation of roughly equipotent theoretical images (Churchland 1978, Hardcastle 1996), the point goes through: ontological dependence does not entail reducibility.

6 - The Ven. Geshe Ngawang Samten, personal communication, and the Ven. Sonam Thackchöe, personal communication. 
7 - And the Jātaka tales include stories of the Buddha doing prima facie rather bad things precisely because on those rare occasions they conduce to the more rapid spiritual benefit of others.

8 - I leave open the option of fighting the other issue out later.

9 - The Ven. Geshe Ngawang Samten (personal communication) points out that another reason for thinking that belief in rebirth is necessary in order to cultivate bodhicitta: one of the principal means of cultivation is the practice of visualizing all sentient beings as one's mother in past lives and developing a feeling of gratitude for their past kindness. If this method were necessary for cultivating bodhicitta, then a belief in past lives would also be necessary for cultivating bodhicitta. But he also points out that this is not the only method for cultivating bodhicitta that is recommended in the tradition, and that the exchange of self for others does not require this belief, and this is widely regarded as sufficient.

10 - Mark Siderits (personal communication) notes that I, like Dharmakīrti and rGyal tshab, rely on causal processes to explain the possibility of Buddhahood, and so that I, like them, presuppose some confidence in causation as a ground of the possibility of bodhicitta, even as I reconceptualize that aspiration. So, he suggests, my view is really no different from theirs. Not so. There is a big difference: whereas the orthodox view I criticize requires (notwithstanding its own protestations to the contrary) a substantial basis for a causal relation, and hence more than mere pratitya-samutpāda, and something like kriyā (bya ba) proper of the kind Nāgārjuna so properly rejects, my account merely requires the kind of causal dependence with which Nāgārjuna properly suggests we should replace causal power and substance talk. What is at issue, I repeat, is neither faith in the existence of the past and the future nor the view that Buddhahood has causes and is difficult to achieve, but rather the claim that personal rebirth is a necessary condition of enlightenment and hence that faith therein is a necessary condition of bodhicitta. And here we differ.

\section{References}

Burge, Tyler. 1979. "Individualism and the Mental." Midwest Studies in Philosophy 4:73-121.

Candrakīrti. 1989. Madhyamakakāvatāra. Translated in C. W. Huntington, Jr. with Geshé Namgyal Wangchen, The Emptiness of Emptiness: An Introduction to Early Indian Mādhyamika. Honolulu: University of Hawai'i Press.

—_. 1994. dBu ma la jugs pa'l ran 'grel. Sarnath: Gleugpa Student Welfare Committee.

Churchland, Paul M. 1978. Scientific Realism and the Plasticity of Mind. Cambridge: Cambridge University Press. 
Cummins, Robert. 1983. The Nature of Psychological Explanation. Cambridge: MIT Press.

Fodor, Jerry A. 1987. Psychosemantics: The Problem of Meaning in the Philosophy of Mind. Cambridge: MIT Press.

Garfield, Jay L. 1988. Belief in Psychology: A Study in the Ontology of Mind. Cambridge: MIT Press.

- 1990. "Epoche and Śūnyatā: Skepticism East and West." Philosophy East and West 40 (3): 285-307.

- 1994. "Dependent Arising and the Emptiness of Emptiness: Why Did Nāgārjuna Start with Causation?" Philosophy East and West 44 (3): 219-250.

- 1995. Fundamental Wisdom of the Middle Way: Nāgārjuna's Mūlamadhyamakakārikā. New York: Oxford University Press.

_ 2000. "Thought as Language: A Metaphor Too Far." Protosociology 14 : 85101.

rGyal tshab rje. 1990. rNam 'grel thar lam gsal byed. Sarnath: Central Institute of Higher Tibetan Studies Gelugpa Student Welfare Committee.

Hardcastle, Valerie Gray. 1996. How to Build a Theory in Cognitive Science. Albany: State University of New York Press.

Haugeland, John. 1981. "The Nature and Plausibility of Cognitivism." Behavior and Brain Science $1: 218-226$.

Kitcher, Philip. 1993. The Advancement of Science: Science without Legend, Objectivity without Illusions. New York: Oxford University Press.

Smart, J. J. C. 1963. Philosophy and Scientific Realism. London: Routledge and Kegan Paul.

Tsong Khapa. 1984. The Essence of True Eloquence. In Tsong Khapa's Speech of Gold in the Essence of True Eloquence: Reason and Enlightenment in the Central Philosophy of Tibet, translated by Robert A. F. Thurman. Princeton: Princeton University Press.

- 1998. Legs bshad snying po. In Geshe Yeshes Thap-khas, Drang nges legs bshad snying po. Sarnath: Central Institute of Higher Tibetan Studies Press.

Van Fraassen, Bas C. 1980. The Scientific Image. Oxford: Clarendon Press.

Von Eckardt, Barbara. 1995. What is Cognitive Science? Cambridge: MIT Press. 